\title{
Financial Performance Mediating the Effect of Corporate Social Responsibility on Corporate Value LQ 45
}

\author{
Siti Sunrowiyati ${ }^{1}$, Grahita Chandrarin ${ }^{2}$, Edi Subiyantoro ${ }^{2}$ \\ ${ }^{1}$ Doctoral Program in Economic Science, University of Merdeka Malang, Indonesia \\ STIE Kesuma Negara Blitar, Indonesia \\ ${ }^{2,3}$ University of Merdeka Malang, Indonesia
}

\begin{abstract}
This study aims to analyze the effect of CSR on financial performance, analyze CSR and financial performance of corporate value, analyze the impact of the financial performance of company value, and analyze the impact of CSR on company value through financial performance. The research design uses explanatory research, which tests the causality between variables through hypotheses that test the influence, relationships or effects of exogenous variables on endogenous variables. The samples in this study were 29 LQ 45 companies. The analysis technique used as many as path analysis. The analysis shows that CSR affects financial performance, which means that the greater the value of CSR issued by the company will be able to benefit the company and improve the quality of the company's financial performance. CSR affects the value of the company, which means that the implementation of CSR directs the effect on the company's value. Financial performance affects the value of the company, this proves that the magnitude of the value of financial performance and relevant information becomes a consideration in making investment decisions in the stock market affect the value of the company. Financial performance mediates the effect of CSR on corporate value, this proves that companies doing CSR can increase company value if financial performance increases.
\end{abstract}

Keywords: CSR, Financial Performance, Corporate value.

\section{INTRODUCTION}

The company's main purpose is to enhance shareholder value. The company's value can increase the wealth of the shareholders, so shareholders did not hesitate to invest the capital that shareholders have told the company. Rise and fall of the company's value is influenced by financial performance, particularly in profitability in generating profits. Profit company other than an indicator of a company's ability to meet obligations to funders is also an element in the creation of value for companies that demonstrate the company's prospects in the future.

The Company has a goal to increase the value of the company, whereas the purpose of business is to provide value and incentive for shareholders [1]. The company's value will increase with the company's financial performance [2]. The financial statements present information company performance is the main tool for management and investors to obtain information [3]. These financial statements are an important component that is often used as a tool to inform the company's performance. The net profit is an indicator of a company's financial performance and can be used by stakeholders as a basis for making decisions in the company [4].

Size used to reflect the company's financial performance there are many kinds. In general, such measures can be divided into three categories, namely ROA and ROE (Waddock and Graves, 2003), profitability in absolute terms [5], and multiple accounting based on the size of the overall index using the score 0-10. However, this study uses the volume of stock trading or Trading Volume Activity (TVA) as an indicator of financial performance. That is because TVA is a projection of the company's revenues [6].

Some of the last period in Indonesia a few companies are trying to approach the community. Various attempts were made in the form of funds and training. This activity is one form of corporate social responsibility or Corporate Social Responsibility. Activity of the company is basically motivated a number of reasons, such as competition between companies, maintain the viability of the company, to avoid conflict with the surrounding community, an obligation which has been regulated by the government in the legislation, as well as to create a good image [7]

Results of research on the influence of corporate social responsibility to corporate value there is a difference. As research conducted by Retno and Priantinah, the disclosure of Corporate Social Responsibility and no significant positive effect on the value of the company with control variables firm size, type of industry, profitability, and leverage the companies listed on the Stock Exchange 2007-2010 [8]. In the control variables firm size has a significant correlation to Corporate Social Responsibility, a 
control variable types of industries have a positive correlation to Corporate Social Responsibility, profitability has a positive correlation to Corporate Social Responsibility, and leverage control variables have a significant correlation to Corporate Social Responsibility.

This study aimed to analyze the effect of CSR on financial performance, analyze CSR and financial performance of the firm value, analyze the impact of the financial performance of the firm value, and analyze the impact of CSR on firm value via financial performance.

\section{LITERATURE REVIEW}

\subsection{Corporate Value}

According Rachmawati and Triatmoko, the value of the company is the sale value of the company or a growing value for shareholders, the company's value will be reflected in the market price of its shares [3]. The company's value according to Nurlela and Islahudin, is defined as the market value [9]. The value of the company can deliver maximum shareholder wealth when the company's stock price to rise. The higher the stock price, the higher the wealth of shareholders. To achieve the company's value generally investors hand over its management to the professionals. The professionals positioned as a manager or commissioner. According to Keown, the value of the company is the market value of debt securities and equity holders of the outstanding shares [10].

\subsection{Corporate Social Responsibility}

Riswari and Cahyonowati explains that the concept of CSR is one of the important milestones in corporate management [11]. Definition of CSR has been proposed by many researchers. Among these are the definition proposed by Boone and Kurtz, the notion of social responsibility (social responsibility) in general is a management support to the obligation to consider profit, customer satisfaction and the welfare of society as equals in evaluating the performance of the company [12].

According Waddock and Graves, the measurement of CSR is a classic problem in the study of CSR, due to a lack of uniformity and various sizes used in the literature [13]. This study uses a CSR index is based on the relative amount spent on social action. CSR Index based information on the three segments of the company's social action: the relationship with employees, external social action and environmental action.

\subsection{Financial performance}

Financial performance represents the performance obtained from the company's performance using debt. Therefore, the use of debt is expected to improve the company's performance. If the debt is used to improve the performance of the company, then the use of debt to benefit the company [14]. According Sudana, the financial performance measurement method is based on the ratio of profitability [15]. The profitability ratio measures the company's ability to generate profits by using the resources of the company as assets, capital, or the sale of the company. Profitability ratios have goals and benefits, not only for the business owner or management, but also for those who have a relationship or interest with the Company.

The ratio of high trading volumes reflect the company's shares are actively traded in the capital market. The ratio of high trading volumes and positive give a positive signal for the company's performance which in turn will have an impact on the strengthening stock prices traded in the capital market. The trading volume illustrates the power between supply and demand which is a reflection of the behavior of investors. With the rising volume of trade, the market situation can be said to be higher, and vice versa [16]. Trading activity in the sector in a very high volume of exchanges will be interpreted as a sign the market will improve (bullish). The increase in trading volume accompanied by an increase in prices is a symptom of increasingly strong bullish conditions [17]

\section{RESEARCH METHODS}

\subsection{Population and Sample}

The population is a collection of elements that have certain characteristics that can be used to make inferences [18]. The population in this study is LQ 45 listed on IDX number of 45 companies. Determination of the number of samples using purposive sampling technique, the sampling method on the basis of certain criteria [18]. The sample used criteria, namely:

a. The sample is LQ 45 listed on the Stock Exchange from 2014 until 2017 and publishes an annual report which can be accessed at www.idx.co.id and Indonesian Capital Market Directory (ICMD).

b. PROPER program of the Ministry of Environment and reporting CSR activities in their annual reports.

c. Published a sustainability report (sustainability reporting) or other social information successively from 2014 until 2017 , because Law No. 40 of 2007.

d. Have complete data related to the variables used in the study.

Based on these criteria, the company LQ 45 listed on the Stock Exchange in 2014 until 2017 as many as 29 companies. 


\subsection{Operational Definition of Variables}

Operational variable definition is the definition explaining how variables are measured and calculated. The scale of measurement is variable and should be Considered part terpemting [18].

\section{a. Corporate Social Responsibility}

Corporate Social Responsibility(CSR) at the company's annual report will be assessed by comparing the number of disclosures by the company. Indicators used in the checklist refer to indicators Global Reporting Initiatives (GRI) G4 which focuses on several components of the disclosure, namely economic, environment, labor practices, human rights, society and product responsibility as the basis for sustainability reporting. Disclosure index is based on each company which is calculated through the number of items actually disclosed the company by the number of all the items that may be disclosed, which is denoted in the following formula.

$\mathrm{CSD}=\frac{n}{\mathrm{k}}$

Information:

$\mathrm{CSD}=\mathrm{CSR}$ disclosure index

$\mathrm{N}=$ the number of items covered CSR

$\mathrm{K} \quad=$ CSR sum of all items (79 items)

b. Financial performance

The financial performance is a picture of a company's financial condition at a particular period both in generating profits. The financial performance of proxies changes in trading volume, as measured by Trading Volume Activity (TVA). By using the volume of stock trading, it can be said that an announcement containing information resulting level of demand for stocks will be higher than the level of the stock offering, so the stock trading volume has increased. Conversely, if an announcement does not contain information about the level of demand for stocks will be lower than the level of the stock offering, so the stock trading volume has decreased.

c. The value of the company

The company's value as measured by Tobin's Q Tobin's Q is calculated using the formula:

Tobin's $\mathrm{Q}=\frac{\mathrm{MVE}+\mathrm{DEBT}}{\mathrm{TA}}$

Information:

MVE = Market value of common equity

DEBT = The book value of debt

TA $=$ total assets

\section{DATA ANALYSIS TECHNIQUE}

\subsection{Analysis Descriptive Statistics}

This analysis is used to describe or depict the circumstances of each variable, namely corporate social responsibility, corporate governance, financial performance and value perusaahaan. By SPSS using descriptive statistics can be seen from each of the variables, such as average value (mean), the minimum and maximum values.

\subsection{Path analysis}

Path analysis (path analysis) is a type of technique multivariate analyzes were used to test the exogenous variables on more than one endogenous variable, in other words, is to examine the effect of direct and indirect (through the intervening variables) variables an independent on the dependent variable that is determined or selected by researchers (Chandrarin, 2017).

\section{RESULTS AND DISCUSSION}

\subsection{Descriptive statistics}

Descriptions of each variable can be presented in Table 1 below.

Table 1 Description Statistics Research

\begin{tabular}{llrrrr}
\hline \multicolumn{1}{c}{ variables } & N & \multicolumn{1}{c}{ Minimum } & \multicolumn{1}{c}{ maximum } & \multicolumn{1}{c}{ mean } & \multicolumn{2}{c}{ Std. deviation } \\
\hline CSR & 116 & 51.03 & 93.10 & 73.2047 & 9.49585 \\
Financial Performance & 116 & 12.78 & 18.67 & 16.3193 & 1.35386 \\
Corporate Value & 116 & 3.73 & 19.39 & 11.8894 & 3.11928 \\
\hline
\end{tabular}

Source: Data processed.

CSR is a concept whereby companies integrate social and environmental concerns in business activity and the board of directors. The higher it isCSR funds are channeled to social activities showed that the higher the company's concern social 
activities and is responsible for the products produced. Proxied by TVA's financial performance period 2014 to 2017 fluctuated. The larger the TVA, it can increase the confidence of investors. Corporate value is an investor perception of the level of success of the company that is closely related to its stock price. High stock price made a firm value is also high, and enhance market confidence not only of the current financial performance but also on the company's prospects for the future.

\subsection{Path coefficient CSR to Financial Performance}

Estimation of the path coefficients demonstrating the influence of CSR on financial performance is done by using regression analysis. The path coefficients obtained from standardized regression coefficients (beta). For more details, description of regression analysis results obtained are presented in Table 2.

Table 2 Path Coefficient Test Results of CSR to Financial Performance

\begin{tabular}{cccc}
\hline variables & Standardized Coefficients Beta & $\mathbf{t}$ & p value \\
\hline CSR & 0.723 & 11.188 & $0.000 *$ \\
\hline
\end{tabular}

* Significant at $\alpha 5 \%$

From Table 2, it can be obtained by the following equation:

$\mathrm{Y} 1=0,723 \mathrm{X} 1$

Based on these equations can be explained that CSR has a significant effect on the financial performance, as evidenced by the significant value of $0.000 \mathrm{t}$ less than $\alpha=0.05$, with a path coefficient of 0.723 .

\subsection{Path coefficient CSR and Financial Performance of The Firm Value}

Estimation of the path coefficients demonstrating the influence of CSR and financial performance of the firm value is done by using regression analysis. The path coefficients obtained from standardized regression coefficients (beta). For more details, description of regression analysis results obtained are presented in Table 3.

Table 3 Path Coefficient Test Results of CSR and Financial Performance Against Corporate value

\begin{tabular}{cccc}
\hline variables & Standardized Coefficients Beta & t & p value \\
\hline CSR & 0.252 & 2,188 & $0,031 *$ \\
\hline Financial Performance & .326 & 2,831 & $0,005 *$ \\
\hline
\end{tabular}

* Significant at $\alpha 5 \%$

From Table 3, it can be obtained by the following equation:

$\mathrm{Y} 2=0,252 \mathrm{X} 1+0,326 \mathrm{Y} 1$

Based on these equations can be explained that CSR has a significant effect on firm value, evidenced by the significant value of $0.031 \mathrm{t}$ less than $\alpha=0.05$, with a path coefficient of 0.252 . The financial performance of a significant effect on firm value, evidenced by the significant value of $0.005 \mathrm{t}$ less than $\alpha=0.05$, with a path coefficient of 0.326 .

Based on the three lines, the overall path analysis results can be presented in Figure 1.

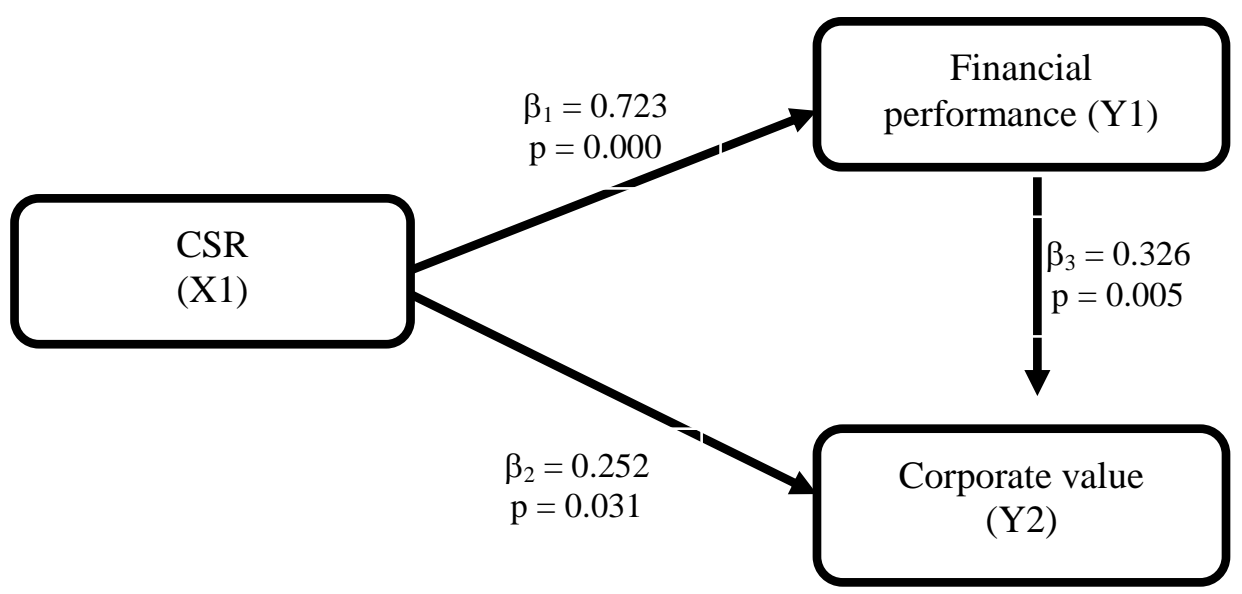

Picture 1 Path Analysis Results of CSR to firm Value Through Financial Performance 
International Journal of Advances in Scientific Research and Engineering (ijasre), Vol 5 (12), December-2019

Effect of Direct, Indirect Influence of CSR to firm Value Through Financial Performance

Based on the results of the analysis of sub-structures 1 and 2 can be arranged substructures indirect effect, the analysis results are presented in Table 4.

Table 4 Effect of Direct, Indirect Influence of CSR to firm Value Through Financial Performance

\begin{tabular}{lccc}
\hline \multicolumn{1}{c}{ Variable } & Direct & Indirect & Total \\
\hline CSR $\rightarrow$ Financial performance & 0.723 & 0.723 \\
CSR $\rightarrow$ Corporate value & 0.252 & 0.252 \\
Financial performance $\rightarrow$ Corporate value & 0.326 & 0.326 \\
$\mathrm{CSR} \rightarrow$ Financial performance $\rightarrow$ Corporate value & 0.252 & $0.723 \times 0.326=0.236$ & 0,488 \\
\hline
\end{tabular}

Based on Table 4, it appears that the total effect of the variable of CSR to firm value (0.488) greater than the direct effect (0.252). These results indicate that the financial performance status as an intervening variable in the effect of CSR on firm value, for a total value greater than the direct effect.

\section{DISCUSSION}

\subsection{Influence of CSR to Financial Performance}

CSR has a significant effect on financial performance, which means that the size of Corporate Social Responsibility has an impact on the company's financial performance. This shows that the application of corporate social responsibility is believed to be able to improve the company's financial performance, where investors tend to invest in companies that carry out CSR activities . Investors are interested in the social information reported in the annual report so that the current management of the company is not only required to be limited to the management of the funds provided, but also includes the impact caused by the company on the natural and social environment. The overall financial performance is a description of the achievements of the company in its operations, both concerning the financial aspects of marketing, collection and distribution of funds, technology and human resources. The existence of reporting and disclosure of Corporate Social Responsibility, the company will be seen as a company that has a high social life, so investors as stakeholders will be more interested in investing in the company. The more investors that enter, of course, the company's income or income will increase. The results of this study are consistent with Pramesti, Crisóstomo et al, Suparjan and Mulya, Suprantiningrum and Asji and Giannarakis et al., Galant and Cadez, Jallo et al. which states that CSR influences financial performance $[19,20,21,22,23,2]$.

\subsection{Effect of CSR on Corporate values}

Corporate social responsibility affects the corporate value. This indicates that the size of corporate social responsibility has an impact on the corporate value. Corporate social responsibility carried out in a company is not only to show concern and legitimize company activities towards stakeholders, but corporate social responsibility is used to protect positions and protect the interests of managers. Investors tend to choose to invest in companies that have good business ethics, practice good employees, care about environmental impacts and have a corporate social responsibility with stakeholders. This statement is based on the idea that companies with these criteria have good communication skills with stakeholders, have a far-reaching vision and are able to recognize warning signals. This allows companies to be able to detect and be more sensitive to any problems and threats that occur and quickly take the opportunities that exist. The results of this study are consistent with Retno and Priantinah and Dianawati and Fuadati, Jallo et al., Gherghina and Vintila which state that CSR is against corporate values [8, 24, 2, 25].

\subsection{Effect of Financial Performance on Corporate values}

The financial performance of a significant effect on firm value, which means that the better the company's financial performance, the higher the value of the firm. This indicates that the information published through the annual financial statements of the relevant information to investors as a basis and consideration in making investment decisions in the capital market, particularly in the buying and selling of shares traded on the Indonesia Stock Exchange. Level of profitability of the company determines the company's ability to generate profits. The financial performance of the company to potential shareholders describe the prospects of companies whose shares will be purchased. The results of this study are in line with Anwar and Masodah, Crisóstomo et al , Purwaningsih and Wirajaya which state that financial performance has an effect on firm value [27, $18,28]$.

\subsection{Influence of CSR to firm Value through Financial Performance}

Corporate value high into the desire of the owners of the company, because with high scores indicate the prosperity of shareholders is also high. Shareholder and the company presented by the market price of the shares is a reflection of the investment decision, financing (financing), and asset management. Corporate value will be reflected in its share price. The market price of shares of the company formed between buyers and sellers when transactions occur is called the company's market value, 
because the price of the stock market is considered a reflection of the true value of the company's assets. Corporate value formed by indicators of stock market value is strongly influenced by investment opportunities. The existence of investment opportunities can give a positive signal about the company's growth in the future, so it will increase the stock price,

\section{CONCLUSIONS AND RECOMMENDATIONS}

\subsection{Conclusion}

This study aimed to analyze the effect of CSR on financial performance, analyze CSR and financial performance of the firm value, analyze the impact of the financial performance of the firm value, and analyze the impact of CSR on firm value via financial performance. CSR affect the financial performance, which means thatthe greater the value of CSR issued by the company will be able to provide benefits for the company and increase the quality of the company's financial performance. CSR effect on firm value, which means that the implementation of CSR companiesdirect effect on firm value. Financial performance effect on firm value, this proves that the magnitude of the value of financial performance is and relevant information into consideration in making investment decisions in the stock market Affect firm value. Financial performance mediates the effect of CSR on firm value, it is proving companies do CSR can increase of firm value, if has Increased financial performance.

\subsection{Recommendation}

For Academics interested in undertaking further research on Corporate Social Responsibility, financial performance and Corporate value can take an object outside the country of Indonesia with a broader scope, and Also to develop the factor - other factors that may be more dominant in Influencing the value of the firm, such as macro-economic conditions, the latest government regulations and can also be Analyzed by other analytical tools.

\section{REFERENCES}

1. Mohamed, M. Bin, \& Sawandi, N. B. (2007). Corporate Social Responsibility (CSR) Activities in Mobile Telecommunication Industry: Case Study of Malaysia. European Critical Accounting Conference, 1-26. Retrieved from http://www.st-andrews.ac.uk/business/ecas/7/papers/ECAS-Mudzamir.pdf

2. Jallo, A., \& Mus, A. R. (2017). Effect of Corporate Social Responsibility, Good Corporate Governance and Ownership Structure on Financial Performance and Firm Value: A Study in Jakarta Islamic Index. IOSR Journal of Business and Management (IOSR-JBM), 19(11), 64-75. https://doi.org/10.9790/487X-1911026475

3. Rachmawati, A., \& Triatmoko, H. (2007). Analisis Faktor-faktor yang Mempengaruhi Kualitas Laba dan Nilai Perusahaan. Simposium Nasional Akuntansi X, 1-26.

4. Weshah, S. R., Dahiyat, A. A, Abu Awwad, M. R., \& Hajjat, E. S. (2012). The Impact of Adopting Corporate Social Responsibility on Corporate Financial Performance: Evidence from Jordanian Banks. Interdisciplinary Journal of Contemporary Research in Business, 4(5), 34-44.

5. Cowen, S., Ferreri, L., \& Parker, L. (1987). The Impact of Corporate Characteristics on Social Responsibility Disclosure: A Typology and Frequency-Based Analysis. Accounting Organizations \& Society. 12(2), 111-122.

6. Beaver, W. H. (1968b). The information content of annual earnings announcements. Empirical Research in Accounting: Selected Studies, 6, 67-92.

7. Rudito, B., \& Famiola, M. (2013). CSR (Corporate Social Responsibility). Bandung: Rekayasa Sains.

8. Retno, R. D., \& Priantinah, D. (2012). Pengaruh Good Coorporate Governance dan Pengungkapan Corporate Social Responsibility terhadap Nilai Perusahaan (Studi Empiris pada Perusahaan yang Terdaftar di Bursa Efek Indonesia Periode 2007-2010). Jurnal Nominal, 1 (1), 84-103.

9. Nurlela, Rika \& Islahuddin. (2008). Pengaruh Corporate Social Responsibility terhadap Nilai Perusahaan dengan Prosentase Kepemilikan Manajemen sebagai Variabel Moderating (Studi Empiris pada Perusahan yang Terdaftar di Bursa Efek Jakarta). Simposium Nasional Akuntansi XI Pontianak.

10. Keown, A. J. (2004). Manajemen Keuangan: Prinsip-Prinsip dan Aplikasi. Jakarta: PT. Indeks Kelompok Gramedia.

11. Riswari, D. A., \& Cahyonowati, N. (2012). Pengaruh Corporate Social Responsibility Tehadap Nilai Perusahaan Dengan Corporate Governance Sebagai Variabel Moderating: Studi Pada Perusahaan Publik Non Finansial Yang Tercatat Di Bursa Efek Indonesia. Diponegoro Journal of Accounting, 1(1), 1-12.

12. Boone, L. E., \& Kurtz, D. L. (2007). Pengantar Bisnis Kontemporer. Jakarta: Salemba Empat.

13. Waddock, S., \& Graves, S. (1997). The Corporate Social Performance-Financial Performance Link. Strategic Management Journal, 18, 303-319.

14. Mulyadi. (2007). Sistem Perencanaan dan Pengendalian Manajemen. Jakarta: Salemba Empat.

15. Sudana, I. M. (2011). Manajemen Keuangan Perusahaan Teori dan Praktek. Jakarta: Erlangga.

16. Ang, R. (1997). Buku Pintar Pasar Modal Indonesia. Jakarta: Mediasoft Indonesia.

17. Husnan, S. (1998). Dasar-dasar Teori Portfolio dan Analisis Sekuritas. Yogyakarta: UPP-AMP YKPN. 
18. Chandrarin, G. (2017). Metode Riset Akuntansi Pendekatan Kuantitatif. Jakarta: Salemba Empat.

19. Pramesti, D., Ekonomi, F., Studi, P., \& Surakarta, U. M. (2012). Pengaruh Corporate Social Responsibility (Csr) terhadap Kinerja Keuangan Perusahaan (Studi Empiris pada Perusahaan Manufaktur yang Terdaftar di Bursa Efek Indonesia Tahun 2008-2010). Naskah Publikasi.

20. Crisóstomo, V. L., De Souza Freire, F., \& De Vasconcellos, F. C. (2011). Corporate social responsibility, firm value and financial performance in Brazil. Social Responsibility Journal, 7(2), 295-309. https://doi.org/10.1108/17471111111141549

21. Suparjan, A., \& Mulya, A. S. (2012). Pengungkapan Corporate Social Responsibility (CSR) sebagai Variabel. Media Riset Akuntansi, Auditing \& Informasi, 12(3), 27-59.

22. Suprantiningrum, \& Asji, S. N. (2014). Pengaruh Moderasi Pengungkapan Corporate Social Responsibility (CSR) dan Good Corporate Governance (GCG) terhadap Hubungan Return on Equity (ROE) dan Nilai perusahaan. Jurnal Untag Semarang, 2(3), 83-97.

23. Glannarakis, G., Konteos, G., Zafeiriou, E., \& Partalidou, X. (2016). The Impact of Corporate Social Responsibility on Financial Performance. Investment Management and Financial Innovations, 13(3), $171-182$. https://doi.org/10.21511/imfi.13(3-1).2016.03

24. Galant, A., \& Cadez, S. (2017). Corporate social responsibility and financial performance relationship: A review of measurement approaches. Economic Research-Ekonomska Istrazivanja, 30(1), 676-693. https://doi.org/10.1080/1331677X.2017.1313122

25. Dianawati, C. P., \& Fuadati, S. R. (2016). Pengaruh Csr Dan Gcg Terhadap Nilai Perusahaan: Profitabilitas Sebagai Variabel Intervening. Jurnal Ilmu Dan Riset Manajemen, 5(1), 1-20.

26. Gherghina, S. C., \& Vintila, G. (2016). Exploring the Impact of Corporate Social Responsibility Policies Oon Firm Value : The Case of Listed Companies in Romania. Economic and Sociology. 9 (1): 23-42.

27. Anwar, D. O., \& Masodah. (2011). Perusahaan dengan Pengungkapan Corporate Social Responsibility dan Kepemilikan Manajerial sebagai Variabel Pemoderasi. Naskah Publikasi, 1-15.

28. Purwaningsih, N. K. I., \& Wirajaya, I. G. A. (2014). Pengaruh Kinerja pada Nilai Perusahaan dengan Corporate Social Resonsibility sebagai Variabel Pemoderisasi. Jurnal Akuntansi dan Keuangan, 7(3), 598-613. 